\title{
Exposure to MTBE, TAME and Aromatic Hydrocarbons during Gasoline Pump Maintenance, Repair and Inspection
}

\author{
Sinikka Vainiotalo ${ }^{1}$, Leea Kunsimäki ${ }^{2}$ and Kaija PeKari ${ }^{1}$ \\ ${ }^{1}$ Finnish Institute of Occupational Health and ${ }^{2}$ Tikkurila Oy, Finland
}

\begin{abstract}
Exposure to MTBE, TAME and Aromatic Hydrocarbons during Gasoline Pump Maintenance, Repair and Inspection: Sinikka Vainiotalo, et al. Finnish Institute of Occupational Health, FinlandThe exposure of gasoline pump repairers and inspectors to gasoline was studied at service stations and repair shops in Finland in April-June 2004. The average air temperature ranged from $7^{\circ} \mathrm{C}$ to $16^{\circ} \mathrm{C}$ and wind speed from 2.5 to $7 \mathrm{~m} / \mathrm{s}$. The gasoline blends contained mixtures of methyl tert-butyl ether (MTBE) and tert-amyl methyl ether (TAME), the total content of oxygenates being $11-12 \%$. The content of benzene was $<1 \%$. Breathing zone air was collected during the work task using passive monitors. The mean sampling period was $4.5 \mathrm{~h}$. The mean TWA-8 h concentrations for MTBE, TAME, hexane, benzene, toluene, ethylbenzene and xylene were 4.5, 1.3, 0.55, 0.23, 2.2, 0.26 and $1.1 \mathrm{mg} / \mathrm{m}^{3}$, respectively. None of the individual benzene concentrations exceeded the binding limit value for benzene $\left(3.25 \mathrm{mg} / \mathrm{m}^{3}\right)$. The sum concentration of MTBE and TAME in urine was between 8.9 and $530 \mathrm{nmol} / \mathrm{l}$ in individual post-shift samples. The individual sum concentrations of the metabolites tertbutyl alcohol and tert-amyl alcohol collected the following morning after the exposure ranged from 81 to $916 \mathrm{nmol} / \mathrm{l}$. All individual results were below corresponding biological action levels. Exposure to aromatic hydrocarbons was estimated from post-shift urine samples, with benzene showing the highest concentration (range 4.4 and $35 \mathrm{nmol} / \mathrm{l}$ in nonsmokers). The exposure levels were similar to those measured in previous studies during unloading of tanker lorries and railway wagons. The results indicated a slightly higher exposure for inspectors, who calibrated fuel pump gauges at the service stations, than for pump repairers. No significant skin exposure occurred during the study.
\end{abstract}

(J Occup Health 2006; 48: 347-357)

Received Jan 23, 2006; Accepted May 17, 2006

Correspondence to: $S$. VAINIOTALO, Finnish Institute of Occupational Health, Topeliuksenkatu 41 a A, FI-00250 Helsinki, Finland (email:sinikka.vainiotalo@ttl.fi)
Key words: Methyl tert-butyl ether, Tert-amyl methyl ether, Benzene, Gasoline pump maintenance, Biological monitoring, Breathing zone air measurement

Gasoline is a mixture of volatile hydrocarbons with a boiling range of $30-200^{\circ} \mathrm{C}$. The reformulated gasoline currently used in several countries contains aliphatic hydrocarbons ca. 50\%, aromatic hydrocarbons ca. $32 \%$ and oxygenates up to $15 \%$. According to current regulations, the benzene content must be $<1 \%$. Because of its severe acute and chronic health effects ${ }^{1)}$, benzene has been one of the main compounds of interest when assessing people's exposure to gasoline. The recent extensive use of oxygenates in gasoline has prompted several studies of oxygenate exposure levels in different tasks. This is especially true for methyl tert-butyl ether (MTBE) and less so for tert-amyl methyl ether (TAME).

Exposure to gasoline has been a long-time concern in many occupational fields, including gasoline transport by tanker lorries, railway tanker wagons or tanker ships, car maintenance work, service stations and the petroleum industry. Data on gasoline exposures in these sectors have been presented in several reports ${ }^{2-9}$. However, very little is known about risks related to the exposure of personnel working on the maintenance and regulatory inspection of service station fuel pumps. For health risk assessment, measurement data are needed on the exposure to oxygenates and other gasoline components during gasoline pump repair and inspection.

Most fuel pump maintenance and repair at service stations is carried out outdoors. The tasks include, for instance, gauge repair, gauge and hose replacement and test runs. Exposure to gasoline via inhalation and skin contact may occur during the whole work period, with inhalation exposure being especially likely when the gasoline is drained from the gauge. Repair work that is carried out indoors often involves exposure to gasoline. On the other hand, indoor test runs of pumps are performed using aliphatic hydrocarbon mixtures instead of gasoline.

Fuel gauges are calibrated in conjunction with periodic 
regulatory inspections at service stations. Inspections are also made after gauge repair. During testing, a minimum of 551 of gasoline per pump pistol is dispensed. First, gasoline is dispensed at a low flow rate into a measuring vessel of 51 and another of 251 , followed by fast dispensing into a vessel of 251 . After measurement, the vessels are emptied into a container which is then unloaded into the service station's underground tank. If the test result is not acceptable, the fuel gauge is adjusted and the test repeated.

At present, half the gasoline pump pistols in Finland are equipped with vapour recovery systems. Inspectors are estimated to be occupationally exposed to gasoline on about 100 days per year and about $5.5 \mathrm{~h}$ at a time (per day), whereas the corresponding estimates of pump repairers are 50-100 $\mathrm{d}$ and $0.5-2 \mathrm{~h}$.

The aim of this study was to determine staff exposure levels during routine maintenance and inspection of gasoline pumps. The measurements were carried out using both air sampling and biological sampling to evaluate total uptake and the role of dermal exposure. The compounds monitored in workers' breathing zone were MTBE, TAME, benzene, toluene, xylene, ethylbenzene and n-hexane. Except ethylbenzene and nhexane, the same compounds or their metabolites were also monitored in worker urine.

\section{Materials and Methods}

Gasoline blends

The study was carried out at service stations and repair shops in southern Finland, where most of the gasoline sold contains an oxygenate mixture of MTBE and TAME. In Finland, 95-RON (research octane number) gasoline accounted for about $90 \%$ of the total amount of gasoline sold in 2004. The oxygenate composition varied among different gasoline blends, but the typical TAME content in the 95 grade was about $7-8 \%$ and the typical MTBE content about $4 \%$. In the 98 grade, the content of TAME was typically about $2 \%$ and the content of MTBE about 9\%. Ethanol was also a possible ingredient in 98-grade gasoline, together with MTBE and TAME. The proportion of aromatic hydrocarbons in the two grades (95 RON and $98 \mathrm{RON}$ ) was $<35 \%$, and that of benzene was $<1 \%$. Summer-grade gasoline with lower vapour pressure was dispensed from the beginning of June, but the change did not affect the composition of the compounds measured in this study.

\section{Participating workplaces and staff}

The exposure measurements were carried out in April, May and June 2004. Five workers from two pump repair shops and three workers from an inspection office participated voluntarily in the study. They were all men between 31 and 56 (mean 44) years of age, and the pump repairers had been working in the trade for 11-31 yr and the inspectors for 1-19 yr. Two of the subjects were smokers (sample sets 1 and 2).

\section{Sampling}

Urine and air samples were collected for assessing exposures to gasoline components. Air samples were collected during the work task in workers' breathing zones using badge-type diffusive monitors (3M OVM 3500; 3M OH\&ESD, 3M Center, St. Paul, MN, USA). The subjects reported the duration of sampling and the duration of potential exposure.

Each study subject was instructed to collect a sample set consisting of one air sample and three spot urine samples, the first one in the morning before the work shift, the second one after the work shift and the third one the following morning. One worker participated in the study twice, providing all the required samples on both occasions (sample sets 6 and 9). Another worker participated in the study on two consecutive days, collecting the required urine and air samples on the first day plus morning urine on the second day (sample set 8). The exposure of the second day was assessed only by air measurement (sample set 10).

The air and urine samples were kept in cool boxes at refrigerator temperature and transported to the laboratory during the second sampling day. The samples were prepared for analysis right after the delivery to the laboratory.

\section{Analysis of air samples}

The air samples were analysed by gas chromatography/ mass spectrometry (GC/MS) after solvent desorption. The charcoal pads of the monitors were desorbed with 2 ml of benzene-free carbon disulphide (Rathburn Chemicals, Walkerburn, UK) for $1 \mathrm{~h}$ with occasional Vortex mixing. The gasoline components were quantified from the eluate with a gas chromatograph (Agilent 6890) equipped with a mass-selective detector in electron ionisation mode (Agilent 5973N). The components were separated in an HP-5 fused silica capillary column $(60 \mathrm{~m}$ $\times 0.25 \mathrm{~mm} \times 1.0 \mu \mathrm{m})$. The following oven temperature programme was used: $40^{\circ} \mathrm{C}$ held for $7 \mathrm{~min}$, increase to $150^{\circ} \mathrm{C}$ at $10^{\circ} \mathrm{C} / \mathrm{min}, 150^{\circ} \mathrm{C}$ held for $7 \mathrm{~min}$. $1 \mu \mathrm{l}$ of the eluate was transferred into the $\mathrm{GC}$ injector port $\left(240^{\circ} \mathrm{C}\right.$, split ratio 1:25) by means of an automatic injector (Agilent 7683). Helium was used as a carrier gas at a constant inlet pressure of $1.34 \mathrm{bar}\left(1.2 \mathrm{ml} / \mathrm{min}\right.$ at $\left.40^{\circ} \mathrm{C}\right)$.

The following ions $(\mathrm{m} / \mathrm{z})$ were chosen for selected ion monitoring of the compounds studied: 73, 57 (MTBE); 57, 86 (hexane); 78, 77 (benzene); 73, 87 (TAME); 91, 92 (toluene); 91, 106 (ethylbenzene); 91,106 (xylene). The abundance of each of the first-mentioned ions was used for quantification. Calibration standards were prepared by the phase equilibrium method by immersing the charcoal pad in a glass vial containing $2 \mathrm{ml}$ of 
calibration mixture in carbon disulphide ${ }^{10)}$.

The limit of quantification (LOQ) was $0.02 \mu \mathrm{g} / \mathrm{sample}$ for MTBE, TAME, ethylbenzene and o-xylene, $0.08 \mu \mathrm{g} /$ sample for benzene and $\mathrm{p} / \mathrm{m}$-xylene, and $0.28 \mu \mathrm{g} / \mathrm{sample}$ for hexane and toluene, corresponding to airborne concentrations of $0.003-0.05 \mathrm{mg} / \mathrm{m}^{3}$ for a sample of 61 . The calculation of TAME concentrations in air was based on a sampling rate of $26.2 \mathrm{ml} / \mathrm{min}$, a value obtained in in-house laboratory tests carried out in a standard atmosphere chamber for the $3 \mathrm{M}$ diffusive monitor. For the rest of the components, uptake values provided by 3M Company were used ${ }^{11)}$.

\section{Analysis of urine samples}

The following compounds were determined in urine: MTBE, its metabolite tert-butyl alcohol (TBA), TAME, its metabolite tert-amyl alcohol (TAA), benzene, toluene and m-xylene.

Head-space gas chromatography with photoionisation detection was used for pre-analysis to obtain the approximate concentrations of the analytes ${ }^{12)}$ prior to quantification using a gas chromatograph and a massselective detector (ion trap) equipped with a solid-phase microextraction (SPME) injector.

\section{SPME-GC-ion trap method}

$500 \mu \mathrm{l}$ of urine or standard solution in water, $100 \mu \mathrm{l}$ of internal standard mixture (2-butanol and chlorobenzene) and about $0.2 \mathrm{~g}$ of $\mathrm{NaCl}$ were placed in a $2-\mathrm{ml}$ vial for about $16 \mathrm{~h}$ for salting out the alcohols before analysis. In SPME mode, the head-space absorption time was 20 min and desorption time $1 \mathrm{~min}$. Polydimethylsiloxane fibers with $100 \mu \mathrm{m}$ film thickness (Supelco) were used as the SPME fibers. The gasoline components and their metabolites were separated using an HP-5MS column (J\&W Scientific, $30 \mathrm{~m} \times 0.25 \mathrm{~mm}$, film $0.25 \mu \mathrm{m}$ ) in less than $7 \mathrm{~min}$. The following GC oven temperature program was used: $40^{\circ} \mathrm{C}$ held for $3 \mathrm{~min}$, increase to $100^{\circ} \mathrm{C}$ at $10^{\circ} \mathrm{C} /$ min, increase to $200^{\circ} \mathrm{C}$ at $30^{\circ} \mathrm{C} / \mathrm{min}, 200^{\circ} \mathrm{C}$ held for 1 $\min$.

The following ions $(\mathrm{m} / \mathrm{z})$ were chosen for selected ion monitoring: 73, 57 (MTBE); 73, 87 (TAME); 59, 41 (TBA); 59, 73 (TAA); 78, 77 (benzene); 91, 92 (toluene); 91,106 (m-xylene). The abundance of each of the firstmentioned ions was used for quantification. The internal standard was chlorobenzene for the aromatics and ethers and 2-butanol for TBA and TAA. The stock solutions for internal standards were prepared in ethanol and the working solutions in water.

The LOQ values for both GC methods were $5 \mathrm{nmol} / \mathrm{l}$ for MTBE, TAME and xylene, $1 \mathrm{nmol} / \mathrm{l}$ for benzene and toluene and $20 \mathrm{nmol} / \mathrm{l}$ for TBA and TAA. The relative standard deviation of the SPME method calculated from double determinations of the samples was $5.5 \%$ for MTBE, $10 \%$ for TBA, $5.3 \%$ for TAME and $3.4 \%$ for
TAA. Recent studies suggest that unmetabolized solvents with low molecular weight are excreted by diffusion into urine $^{13)}$ and all urinary measurements of this study are reported without correction by relative density.

The SAS program was used for calculations. Each result below the LOQ was assigned a value of half the LOQ.

\section{Results}

The characteristics of exposure measurements (e.g. air sampling periods, weather conditions and work description) are presented in Table 1. Gloves-but no respiratory protection equipment-were used for personal protection. The individual results of breathing zone air measurements are in Table 2. The mean concentrations for the eight compounds measured (MTBE, hexane, benzene, TAME, toluene, ethylbenzene, $\mathrm{m}+\mathrm{p}$-xylene and o-xylene) ranged from 0.62 (benzene) to $11 \mathrm{mg} / \mathrm{m}^{3}$ (MTBE). The mean sampling period was $4.5 \mathrm{~h}$ (range 1.5 to $7.8 \mathrm{~h}$ ). A time-weighted concentration for eight hours (TWA-8 h) was also calculated for each individual measurement (Table 2).

As the measurements were made for different work descriptions, the air samples were divided into three groups (pump repair outdoors, pump repair indoors, pump gauge calibration outdoors). The average and range values for all compounds measured in these groups are presented in Table 3 with the corresponding TWA- $8 \mathrm{~h}$ concentrations. The sampling periods were longest (often the whole working day) in pump calibration work (2.8$7.8 \mathrm{~h}$ ), whereas both exposure and sampling periods were shorter in pump repair.

The individual urinary concentrations of benzene, toluene, m-xylene, MTBE, its metabolite TBA, TAME and its metabolite TAA and corresponding amounts in air samples (as $\mu \mathrm{g} / \mathrm{sample}$ ) are compiled in Table 4 . There are three urinary results in each sample set: first urine sample collected before the work shift (pre), the second after the work shift (post) and the third the following morning (next). Exposure to MTBE was observed in all sample sets, as all post-shift concentrations exceeded the corresponding pre-shift values. Exposure to TAME was found in only four out of nine sample sets. An elevated post-shift benzene level was observed in all seven nonsmoker subjects and an elevated post-shift toluene level in five non-smokers. For the two smokers among the study subjects, benzene and toluene levels were inconsistent with the exposure period. m-xylene concentrations were below LOQ in all measurements except one post-shift reading for a non-smoker.

Table 5 presents individual and work-type average urinary concentrations and ranges for the most appropriate indicators of exposure: benzene concentration after the work shift (post) and the sum concentrations MTBE + TAME after the work shift (post) and TBA + TAA the 


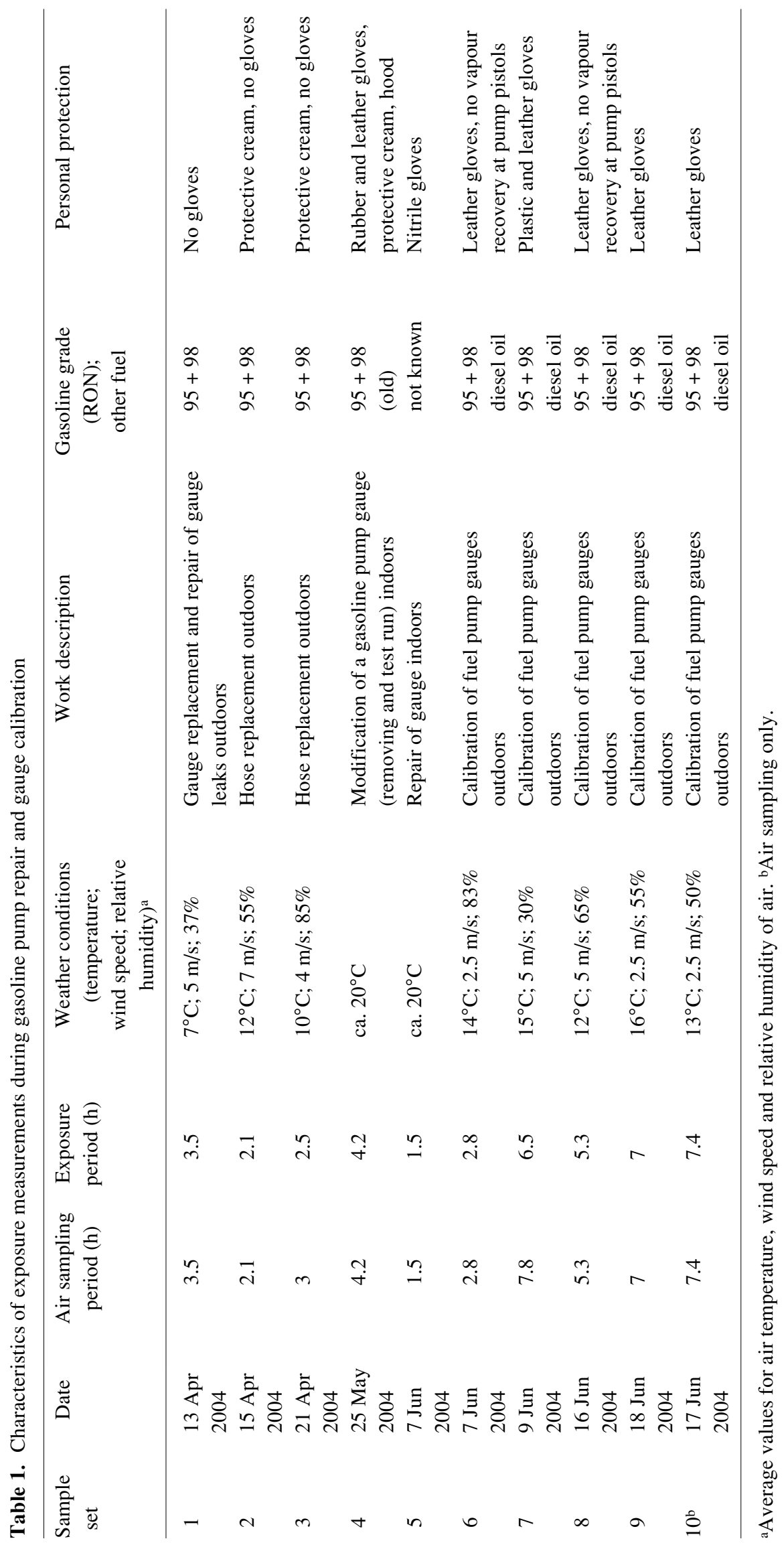




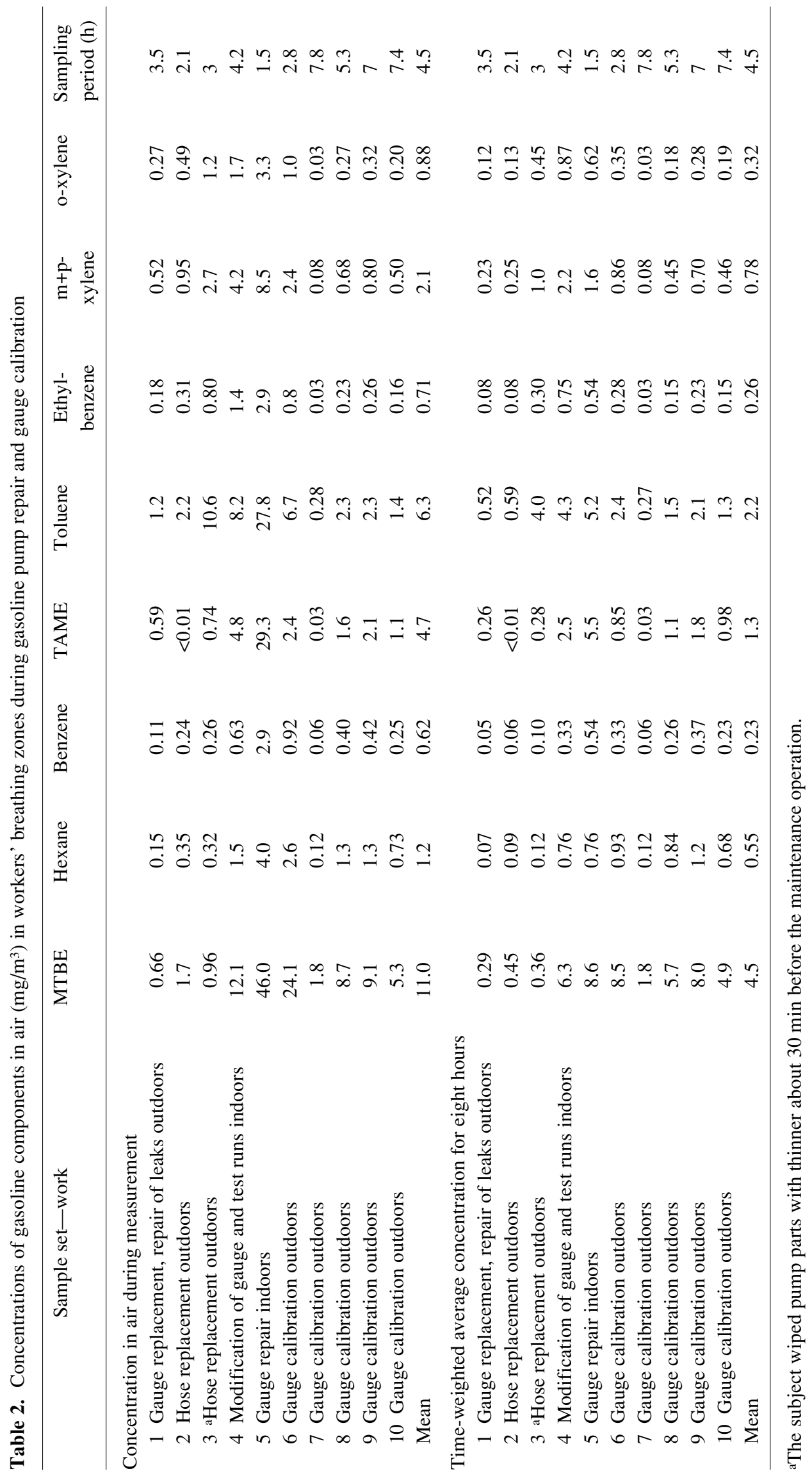




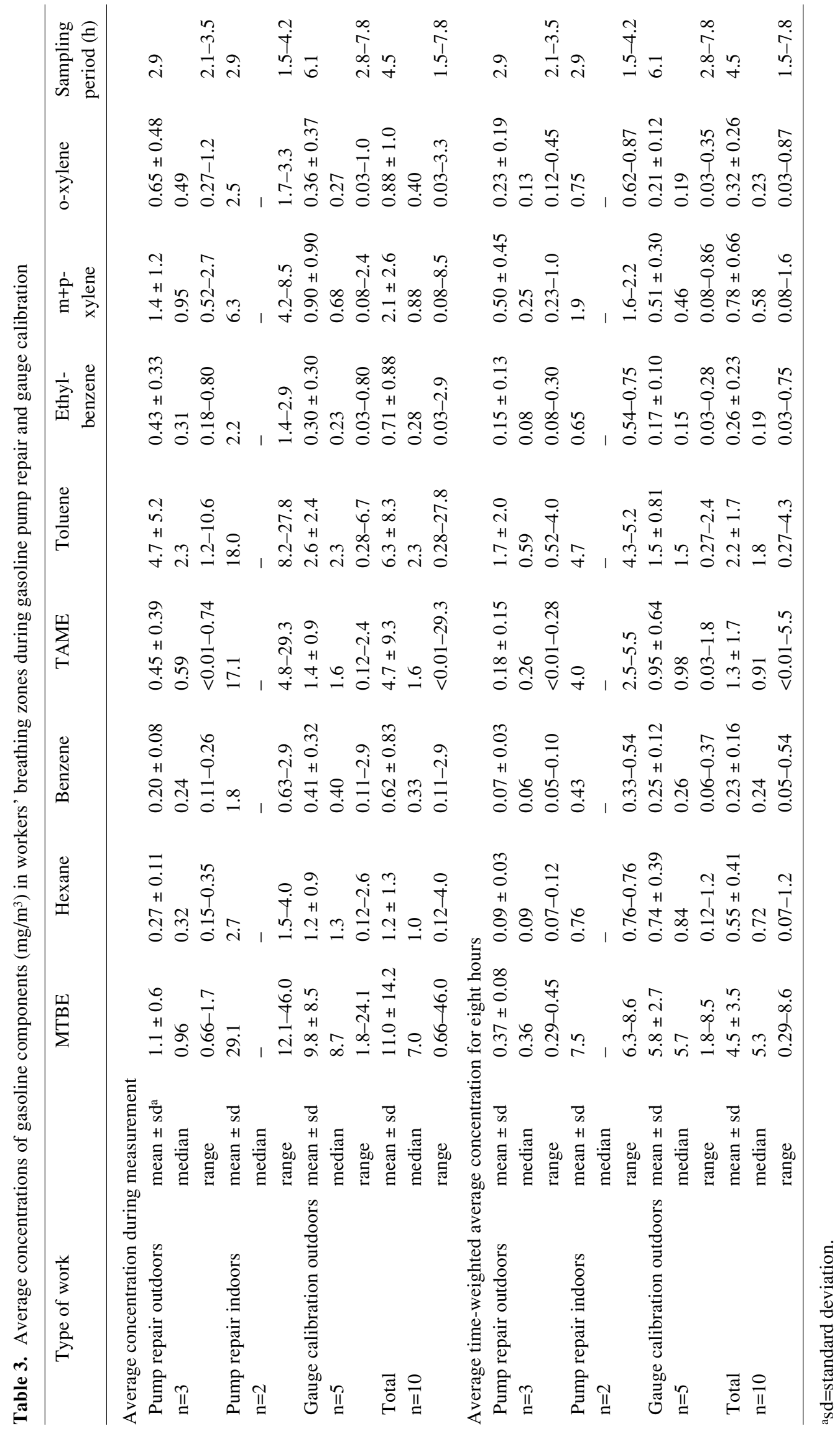


Table 4. Urinary concentrations of compounds measured in connection with gasoline pump repair and gauge calibration work and corresponding concentrations in air samples (continued on next page)

\begin{tabular}{|c|c|c|c|c|c|c|}
\hline Compound & Work $^{\mathrm{a}}$ & $\begin{array}{c}\text { Sample } \\
\text { set }\end{array}$ & $\begin{array}{c}\text { Pre } \\
(\mathrm{nmol} / \mathrm{l})\end{array}$ & $\begin{array}{l}\text { Ine samples } \\
\text { Post } \\
(\mathrm{nmol} / \mathrm{l})\end{array}$ & $\begin{array}{c}\text { Next } \\
(\mathrm{nmol} / \mathrm{l})\end{array}$ & $\begin{array}{r}\text { Personal } \\
\text { air sample } \\
(\mu \mathrm{g} / \mathrm{sample})\end{array}$ \\
\hline MTBE & A & 1 & 10 & 23 & $<5.0$ & 4.3 \\
\hline TBA & & 1 & 67 & 194 & 148 & \\
\hline TAME & & 1 & $<5.0$ & $<5.0$ & $<5.0$ & 3.2 \\
\hline TAA & & 1 & $<20$ & $<20$ & $<20$ & \\
\hline Benzene & & 1 & 14 & 6.3 & 5.3 & 0.80 \\
\hline Toluene & & 1 & 5.6 & 3.9 & 2.4 & 7.9 \\
\hline m-Xylene & & 1 & $<5.0$ & $<5.0$ & $<5.0$ & 3.0 \\
\hline MTBE & A & 2 & 16 & 106 & 8.3 & 6.7 \\
\hline TBA & & 2 & 412 & 601 & 315 & \\
\hline TAME & & 2 & $<5.0$ & $<5.0$ & $<5.0$ & $<0.02$ \\
\hline TAA & & 2 & $<20$ & $<20$ & $<20$ & \\
\hline Benzene & & 2 & 5.6 & 4.5 & 74 & 1.1 \\
\hline Toluene & & 2 & 6.3 & 5.5 & 3.9 & 8.8 \\
\hline m-Xylene & & 2 & $<5.0$ & $<5.0$ & $<5.0$ & 3.3 \\
\hline MTBE & A & 3 & 15 & 125 & 21 & 5.4 \\
\hline TBA & & 3 & 113 & 396 & 442 & \\
\hline TAME & & 3 & 7.0 & 17 & 8.0 & 3.5 \\
\hline TAA & & 3 & $<20$ & 40 & 25 & \\
\hline Benzene & & 3 & 7.6 & 35 & 23 & 1.7 \\
\hline Toluene & & 3 & 2.8 & 27 & 9.4 & 60 \\
\hline m-Xylene & & 3 & $<5.0$ & $<5.0$ & $<5.0$ & 13 \\
\hline MTBE & B & 4 & $<5.0$ & 257 & 24 & 94 \\
\hline TBA & & 4 & 48 & 1520 & 843 & \\
\hline TAME & & 4 & $<5.0$ & 46 & 7.0 & 32 \\
\hline TAA & & 4 & $<20$ & 343 & 73 & \\
\hline Benzene & & 4 & 2.3 & 5.8 & 23 & 5.6 \\
\hline Toluene & & 4 & 8.7 & 21 & 7.1 & 64 \\
\hline m-Xylene & & 4 & $<5.0$ & 5.9 & $<5.0$ & 29 \\
\hline MTBE & B & 5 & $<5.0$ & 6.4 & $<5.0$ & 127 \\
\hline TBA & & 5 & 32 & 62 & 71 & \\
\hline TAME & & 5 & $<5.0$ & $<5.0$ & $<5.0$ & 69 \\
\hline TAA & & 5 & $<20$ & $<20$ & $<20$ & \\
\hline Benzene & & 5 & 1.0 & 4.3 & 2.3 & 9.2 \\
\hline Toluene & & 5 & 6.1 & 4.9 & 3.4 & 79 \\
\hline m-Xylene & & 5 & $<5.0$ & $<5.0$ & $<5.0$ & 21 \\
\hline MTBE & $\mathrm{C}$ & 6 & $<5.0$ & 98 & 6.0 & 126 \\
\hline TBA & & 6 & 82 & 261 & 233 & \\
\hline TAME & & 6 & $<5.0$ & $<5.0$ & $<5.0$ & 11 \\
\hline TAA & & 6 & $<20$ & 25 & $<20$ & \\
\hline Benzene & & 6 & $<1.0$ & 4.4 & 5.1 & 5.5 \\
\hline Toluene & & 6 & $<1.0$ & 3.4 & 2.7 & 36 \\
\hline m-Xylene & & 6 & $<5.0$ & $<5.0$ & $<5.0$ & 11 \\
\hline
\end{tabular}


(continued)

Table 4. Urinary concentrations of compounds measured in connection with gasoline pump repair and gauge calibration work and corresponding concentrations in air samples

\begin{tabular}{|c|c|c|c|c|c|c|}
\hline Compound & Work $^{\mathrm{a}}$ & $\begin{array}{c}\text { Sample } \\
\text { set }\end{array}$ & $\begin{array}{c}\text { Pre } \\
(\mathrm{nmol} / \mathrm{l})\end{array}$ & $\begin{array}{c}\text { ine samples } \\
\text { Post } \\
(\mathrm{nmol} / \mathrm{l})\end{array}$ & $\begin{array}{c}\text { Next } \\
(\mathrm{nmol} / \mathrm{l})\end{array}$ & $\begin{array}{r}\text { Personal } \\
\text { air sample } \\
(\mu \mathrm{g} / \mathrm{sample})\end{array}$ \\
\hline MTBE & $\mathrm{C}$ & 7 & $<5.0$ & 47 & 10 & 26 \\
\hline TBA & & 7 & $<20$ & 294 & 87 & \\
\hline TAME & & 7 & $<5.0$ & $<5.0$ & $<5.0$ & 0.41 \\
\hline TAA & & 7 & $<20$ & $<20$ & $<20$ & \\
\hline Benzene & & 7 & 2.0 & 16 & 3.3 & 1.1 \\
\hline Toluene & & 7 & $<1.0$ & $<1.0$ & $<1.0$ & 4.1 \\
\hline m-Xylene & & 7 & $<5.0$ & $<5.0$ & $<5.0$ & 1.0 \\
\hline MTBE & $\mathrm{C}$ & 8 & $<5.0$ & 489 & 22 & 84 \\
\hline TBA & & 8 & 38 & 1090 & 664 & \\
\hline TAME & & 8 & $<5.0$ & 41 & $<5.0$ & 13 \\
\hline TAA & & 8 & $<20$ & 192 & 37 & \\
\hline Benzene & & 8 & $<1.0$ & 15 & 15 & 4.5 \\
\hline Toluene & & 8 & 1.5 & 11 & 2.4 & 23 \\
\hline m-Xylene & & 8 & $<5.0$ & $<5.0$ & $<5.0$ & 5.9 \\
\hline MTBE & $\mathrm{C}$ & 9 & 23 & 357 & 116 & 118 \\
\hline TBA & & 9 & 77 & 654 & 670 & \\
\hline TAME & & 9 & 19 & 147 & 78 & 23 \\
\hline TAA & & 9 & $<20$ & 120 & 86 & \\
\hline Benzene & & 9 & 3.2 & 7.6 & 9.6 & 6.3 \\
\hline Toluene & & 9 & 3.0 & 4.3 & 5.2 & 31 \\
\hline m-Xylene & & 9 & $<5.0$ & $<5.0$ & $<5.0$ & 9.2 \\
\hline
\end{tabular}

${ }^{\mathrm{a}} \mathrm{A}=$ pump repair outdoors, $\mathrm{B}=$ pump repair indoors, $\mathrm{C}=$ gauge calibration outdoors.

following morning (next). For the individual samples, there was a significant positive correlation between the exposure indicators MTBE + TAME and TBA + TAA (Pearson's coefficient of correlation, $r=0.86$ ), which confirmed the reliability of the urine sampling carried out by the study subjects themselves.

In Tables 4 and 5, airborne concentrations are given in $\mu \mathrm{g} / \mathrm{sample}$, thus allowing correlation of levels in urine samples with the actual exposures through the respiratory route. As the sampling rate for a diffusive sampler and for a known substance is constant, the amount of a compound on the sampler is proportional to the concentration in air $\times$ sampling time. The amount of a substance on the sampler could thus be directly used for the calculation of correlation. An $r$ value of 0.65 was obtained between MTBE + TAME in air and MTBE + TAME in urine (when sample set 5 was excluded), but this correlation was not statistically significant. In all, there was no linear correlation between the airborne concentrations of MTBE, TAME or benzene and the corresponding urinary levels.

\section{Discussion}

The weather was rather cold and windy during these measurements in southern Finland, with outdoor temperatures ranging from $7^{\circ} \mathrm{C}$ to $16^{\circ} \mathrm{C}$ (mean $12.4^{\circ} \mathrm{C}$, $\mathrm{n}=8$ ). Consequently, both urine and air measurements in association with outdoor work tasks showed lower levels of exposure than expected for the time of year.

Only two sample sets related to pump repair work indoors (sample sets 4 and 5). For sample set 4, the subject used a hood during air sampling, whereas no hood was used during air sampling for sample set 5 . The latter set yielded relatively high concentrations in air, but all the biomarkers in urine indicated low exposure. The higher airborne concentrations compared with levels in urine could be due to contamination of the monitor by a splash of solvent, or the subject may have handled the monitor with gasoline-contaminated hands.

For the hydrocarbon compounds (benzene, toluene, xylene, ethylbenzene and hexane), the lowest airborne concentrations were measured for benzene and the highest 
Table 5. Individual and average values of exposure indicators in gasoline pump repair and gauge calibration

\begin{tabular}{|c|c|c|c|c|c|c|}
\hline $\begin{array}{c}\text { Type of } \\
\text { work/ } \\
\text { sample } \\
\text { set }\end{array}$ & & $\begin{array}{c}\text { MTBE+ } \\
\text { TAME } \\
\text { in urine } \\
\text { post } \\
\text { nmol/l }\end{array}$ & $\begin{array}{c}\text { TBA+TAA } \\
\text { in urine } \\
\text { next } \\
\text { nmol/l }\end{array}$ & $\begin{array}{l}\text { Benzene } \\
\text { in urine } \\
\text { post } \\
\mathrm{nmol} / \mathrm{l}\end{array}$ & $\begin{array}{c}\text { MTBE+ } \\
\text { TAME } \\
\text { in air } \\
\mu \mathrm{g} / \mathrm{sample}\end{array}$ & $\begin{array}{c}\text { Benzene } \\
\text { in air } \\
\mu \mathrm{g} / \text { sample }\end{array}$ \\
\hline $\mathrm{A} / 1$ & & 26 & 158 & 6.3 & 7.5 & 0.8 \\
\hline $\mathrm{A} / 2$ & & 109 & 325 & 4.5 & 6.7 & 1.1 \\
\hline $\mathrm{A} / 3$ & & 142 & 467 & 35 & 8.9 & 1.7 \\
\hline $\mathrm{A} / 1-3$ & mean & 92 & 317 & 15 & 7.7 & 1.2 \\
\hline $\mathrm{A} / 1-3$ & median & 109 & 325 & 6.3 & 7.5 & 1.1 \\
\hline $\mathrm{A} / 1-3$ & range & $26-142$ & $158-467$ & $4.5-35$ & $6.7-8.9$ & $0.8-1.7$ \\
\hline $\mathrm{B} / 4$ & & 303 & 916 & 5.8 & 126 & 5.6 \\
\hline $\mathrm{B} / 5$ & & 8.9 & 81 & 4.3 & 196 & 9.2 \\
\hline $\mathrm{B} / 4-5$ & mean & 156 & 499 & 5.1 & 161 & 7.4 \\
\hline $\mathrm{B} / 4-5$ & median & - & - & - & - & - \\
\hline $\mathrm{B} / 4-5$ & range & $8.9-303$ & $81-916$ & $4.3-5.8$ & $126-196$ & $5.6-9.2$ \\
\hline $\mathrm{C} / 6$ & & 101 & 243 & 4.4 & 137 & 5.5 \\
\hline $\mathrm{C} / 7$ & & 50 & 97 & 16 & 26 & 1.1 \\
\hline $\mathrm{C} / 8$ & & 530 & 701 & 15 & 97 & 4.5 \\
\hline $\mathrm{C} / 9$ & & 504 & 756 & 7.6 & 141 & 6.3 \\
\hline C/6-9 & mean & 296 & 449 & 11 & 100 & 4.0 \\
\hline $\mathrm{C} / 6-9$ & median & 302 & 472 & 11 & 117 & 5.0 \\
\hline C/6-9 & range & $50-530$ & $97-756$ & $4.4-16$ & 26-141 & $1.1-6.3$ \\
\hline \multirow[t]{3}{*}{ All } & mean & 197 & 416 & 11 & 83 & 4.0 \\
\hline & median & 109 & 325 & 6.3 & 97 & 4.5 \\
\hline & range & $8.9-530$ & $81-916$ & $4.3-35$ & $6.7-196$ & $1.1-9.2$ \\
\hline
\end{tabular}

post=sampling after work shift, next=sampling the following morning after previous day's work shift, $\mathrm{A}=$ pump repair outdoors, $\mathrm{B}=$ pump repair indoors, $\mathrm{C}=$ gauge calibration outdoors.

for toluene, the content of which in gasoline is ca. $8 \%$. The highest concentrations of the five hydrocarbon compounds were $0.3-17 \%$ of the corresponding occupational limit value ${ }^{14)}$. Benzene is a carcinogen with a binding limit value of $3.25 \mathrm{mg} / \mathrm{m}^{3}{ }^{14-15)}$. This limit value is much lower than the reference values for the other hydrocarbons measured in this study: $190 \mathrm{mg} / \mathrm{m}^{3}$ (toluene), $220 \mathrm{mg} / \mathrm{m}^{3}$ (xylene and ethylbenzene) and 72 $\mathrm{mg} / \mathrm{m}^{3}$ (hexane).

With regard to the choice of biomarkers (the hydrocarbon compounds, the ethers and their primary metabolites, tertiary alcohols), a previous gasoline study) showed a correlation between their airborne exposure concentrations and the biological results. Furthermore, all the determinations of the individual substances could be carried out from the same urine sample. In general, the advantage of using unmetabolized compounds as biomarkers is that the urinary concentration of the unmetabolized substance is less influenced by interindividual metabolic differences than the urinary disposition of corresponding metabolites.
However, there was a considerable difference between the urinary levels of benzene and the higher aromatics, toluene and xylene, as the latter scarcely dissolve in water phase (urine). Since the concentrations of toluene and xylene in urine were low or below the LOQ, gasoline exposure could not be reliably estimated from these components at the airborne concentrations encountered in this study. Benzene, which dissolves fairly well in the water phase, occurs at higher levels in urine even after low exposure. For the sake of low solubility in water, the urinary levels of n-hexane and ethylbenzene could not be measured using the SPME method. We also reasoned that there was no point in measuring these compounds using a different method-based on their urinary metabolites - at these low exposure levels.

Because tobacco smoke contains benzene, the urinary concentrations of benzene are higher (on average $24 \mathrm{nmol} /$ 1) in smokers than non-smokers ${ }^{5}$. In this study, the urinary benzene concentration of one worker (sample set 2) was much higher the next morning $(74 \mathrm{nmol} / \mathrm{l})$ than immediately after working hours. The high morning level 
does indicate exposure, but one that is more recent than the last working day. A concentration as high as $74 \mathrm{nmol} /$ 1 may be explained — but hardly fully — by smoking. The confounding effect of smoking was also seen in the case of toluene in sample sets 1 and 2 .

In this study, the concentration of benzene in workers' breathing zones ranged from 0.05 to $0.37 \mathrm{mg} / \mathrm{m}^{3}$ (TWA$8 \mathrm{~h}$ ) when sample set 5 was excluded. The corresponding post-shift urinary benzene levels were between 4.4 and $35 \mathrm{nmol} / \mathrm{l}$ for non-smokers. No BAL (biomonitoring action limit) value has been published for urinary benzene. The benzene levels measured for pump repairers and inspectors in this study are consistent with the levels previously measured during the unloading of tanker lorries and railway wagons. At the previously reported exposure levels of $0.02-0.6 \mathrm{mg} / \mathrm{m}^{3}$ (TWA- $8 \mathrm{~h}$ ), the urinary post-shift benzene levels of occupationally exposed workers ranged from $<5$ to $46 \mathrm{nmol} / \mathrm{l}$ for non-smokers and from 7 to $65 \mathrm{nmol} / \mathrm{l}$ for smokers ${ }^{5}$.

Exposure to tertiary ethers can be assessed by the sum of the ethers (MTBE + TAME) in a post-shift urine sample and/or the sum of the alcohol metabolites (TBA + TAA) in a urine sample the following morning after the exposure $^{16)}$. In this study, the individual levels for MTBE + TAME in post-shift urine samples ranged from 8.9 to $530 \mathrm{nmol} / \mathrm{l}$ (mean $197 \mathrm{nmol} / \mathrm{l}$ ) and were thus well below the corresponding BAL value of $10,000 \mathrm{nmol} / \mathrm{I}^{16)}$. It should be noted, however, that BAL values refer to constant exposure during working hours.

The urinary excretion of alcohol metabolites is slower than that of the parent ethers; thus they represent average exposure of the work period. Therefore, if the airborne concentrations vary widely during working hours, the urinary concentration of the metabolites TBA + TAA in a next morning sample is often the best exposure indicator. The individual sum concentrations of TBA and TAA in urine ranged from 81 to $916 \mathrm{nmol} / \mathrm{l}$, being 3-30\% of the corresponding BAL value $(3,000 \mathrm{nmol} / \mathrm{l})$. The mean value was $416 \mathrm{nmol} / \mathrm{l}$. The highest values measured for these tert-alcohol metabolites (TBA + TAA) in next morning urine samples were $23 \%, 25 \%$ and $30 \%$ (sample sets 8,9 and 4 ) of the above-mentioned $\mathrm{BAL}^{16}$. Two of these three subjects were inspectors and one was a pump repairer. Oxygenate levels similar to the ones obtained in this study have been found in exposure measurements of tanker lorry drivers ${ }^{5,12,17)}$. Based on a previous study there is evidence that the MTBE, TAME, TBA and TAA levels of unexposed persons remain below the detection $\operatorname{limits}^{17)}$.

The total oxygenate (MTBE and TAME) content in gasoline was $11-12 \%$. MTBE is more volatile than TAME and airborne MTBE therefore usually occurs at higher concentrations than TAME, even if TAME is the main component in the oxygenate mixture. The MTBE concentrations in workers' breathing zones were $0.2-5 \%$ of the 8-h hygienic reference value of $180 \mathrm{mg} / \mathrm{m}^{3}{ }^{14,18)}$. No reference value has been set for TAME in Finland, but the threshold limit value (TLV) published by the American Conference of Governmental Industrial Hygienists (ACGIH) is $85 \mathrm{mg} / \mathrm{m}^{3}$ (20 ppm). The highest measured value for TAME was $6 \%$ of the 8 -h TLV. The concentration of TAME was lower than that of MTBE in all individual breathing zone measurements. The concentrations in workers' urine appeared consistent with the breathing zone measurements, ruling out any substantial exposure through the skin. On the other hand, the lack of statistical significance in this respect may, in addition to reflecting the small set of measurement data, suggest some degree of transdermal exposure. For instance, similar airborne MTBE concentrations were measured for sample sets 6 and 9, but the urinary levels of MTBE/TBA were clearly higher for sample set 9 . The corresponding difference between urinary benzene levels was not as high as that of MTBE/TBA. A possible explanation may be different permeation properties.

There may be a significant risk of dermal exposure, especially since proper chemical protective gloves did not seem to be in common use. Leather gloves or plasticor rubber-coated textile gloves were commonly used in pump repair and maintenance but seldom during the whole work period. Some workers also applied protective cream to their hands before starting work. Leather work gloves were commonly worn by the inspectors (Table 1). The role of the dermal exposure route varies among different gasoline components and depends on compoundspecific permeation coefficients. For instance, a permeation coefficient of $0.028 \mathrm{~cm} / \mathrm{h}$ has been measured for MTBE, indicating moderate dermal penetration, and it is likely that TAME has a similar permeation coefficient ${ }^{19)}$. All the hydrocarbon compounds measured in this study are also known to permeate the skin ${ }^{20)}$.

Under the EU Risk Assessment Procedure, reasonable worst-case exposures based on TAME measurements have been calculated for typical work tasks involving TAME or TAME-containing gasoline. The work tasks were ranked according to descending 90th-percentile TWA-8 h TAME concentration as follows: fuel pump repairs, car refuelling by service station attendants, manufacturing and waste handling, car engine repairs, transport, distribution and onsite production (personal communication, Dr. Kerstin Engström, Laboratory Manager, Turku, Finnish Institute of Occupational Health, 2005). According to the above, gasoline pump repairers belong to the most exposed population, however, the range of exposures to TAME was not wide $\left(0.6-3.5 \mathrm{mg} / \mathrm{m}^{3}\right)$ among the different occupational groups. In general, the measured airborne concentrations of gasoline components in different work tasks tend to be quite similar, which was also shown by our previous measurements concerning the gasoline distribution chain $^{5,12,17)}$ 
It is evident that the exposure of gasoline pump repairers and inspectors depends on meteorological conditions $^{3,21)}$. Higher airborne concentrations than measured in this study will occur at higher temperatures and lower wind speeds.

In conclusion, inspectors who calibrated the gasoline pump gauges at service stations were found to be probably the most exposed group in this study. Inhalation is presumably inspectors' principal route of exposure. The individual concentrations in breathing zone air and in urine were comparable to the levels measured in previous studies during the loading and unloading of tanker lorries and railway wagons. No significant transdermal exposure was observed.

Acknowledgments: The authors are grateful to CONCAWE and Fortum Oil and Gas Oy for financial support. We also wish to thank Dr. Kerstin Engström for valuable comments and information as well as Eevi Nieminen and Yrjö Peltonen for skilful technical assistance.

\section{References}

1) van Wijngaarden E and Stewart P: Critical literature review of determinants and levels of occupational benzene exposure for United States community-based case-control studies. Appl Occup Environ Hyg 18, 678 693 (2003)

2) Laitinen J, Kangas J, Pekari K and Liesivuori J: Shorttime exposure to benzene and gasoline at garages. Chemosphere 28, 197-205 (1994)

3) Vainiotalo $S$ and Ruonakangas A: Tank truck driver exposure to vapors from oxygenated or reformulated gasoline during loading and unloading. Am Ind Hyg Assoc J 60, 518-525 (1999)

4) Davenport AC, Glynn TJ and Rhambarose H: Coast guard exposure to gasoline, MTBE, and benzene vapors during inspection of tank barges. Am Ind Hyg Assoc $\mathbf{J}$ 61, 865-872 (2000)

5) Hakkola M, Saarinen L and Pekari K: Exposure to gasoline vapour during offloading of tankers and railway wagons and biological multicomponent monitoring. J Occup Health 43, 287-290 (2001)

6) Verma DK, Johnson DM, Shaw ML and des Tombe K: Benzene and total hydrocarbon exposures in the downstream petroleum industries. Am Ind Hyg Assoc J 62, 176-194 (2001)

7) Egeghy PP, Nylander-French L, Gwin KK, HertzPicciotto I and Rappaport S: Self-collected breath sampling for monitoring low-level benzene exposures among automobile mechanics. Ann Occup Hyg 46, 489-500 (2002)

8) Verma DK, Cheng WK, Shaw DS, Shaw ML, Verma P, Julian JA, Dumschat RE and Mulligan SJP: A simultaneous job- and task-based exposure evaluation of petroleum tanker drivers to benzene and total hydrocarbons. J Occup Environ Hyg 1, 725-737 (2004)

9) Periago JF and Prado C: Evolution of occupational exposure to environmental levels of aromatic hydrocarbons in service stations. Ann Occup Hyg 49, 233-240 (2005)

10) Dommer RA and Melcher RG: Phase equilibrium method for determination of desorption efficiences. Am Ind Hyg Assoc J 39, 240-246 (1978)

11) $3 \mathrm{M}$ Technical Data Bulletin. Organic Vapor MonitorSampling and Analysis Guide. (online), available from <http://www.3m.com>, (Accessed 2006-08-22)

12) Saarinen L, Hakkola M, Pekari K, Lappalainen K and Aitio A: Exposure of gasoline road-tanker drivers to methyl tert-butyl ether and methyl tert-amyl ether. Int Arch Occup Environ Health 71, 143-147 (1998)

13) Kawai T, Zwang ZW, Takeuchi A, Miyama Y, Sakamoto K, Higashikawa K and Ikeda M: Methyl isobutyl ketone and methyl ethyl ketone in urine as biological markers of occupational exposure to these solvents at low levels. Int Arch Occup Environ Health 76, 17-23 (2003)

14) Ministry of Social Affairs and Health. HTP values 2005. Handbooks of the Ministry of Social Affairs and Health 2005:10. Helsinki: Ministry of Social Affairs and Health, 2005.

15) European Directive: Council Directive 97/42/EC of 27 June 1997 amending for the first time Directive 90/ 394/EEC on the protection of workers from the risks related to exposure to carcinogens at work. Official Journal of the European Communities L179, 4-6 (1997)

16) Finnish Institute of Occupational Health. Biomonitoring of exposure to chemicals-Guideline for specimen collection. Helsinki: Biomonitoring Laboratory, 2004.

17) Vainiotalo S, Pekari K and Aitio A: Exposure to methyl tert-butyl ether and tert-amyl methyl ether from gasoline during tank lorry loading and its measurement using biological monitoring. Int Arch Occup Environ Health 71, 391-396 (1998)

18) ACGIH. TLVs and BEIs based on the documentation of the threshold limit values for chemical substances and physical agents \& biological exposure indices. Cincinnati, Ohio: American Conference of Governmental Industrial Hygienists, 2006.

19) Prah J, Ashley D, Blount B, Case M, Leavens T, Pleil $\mathrm{J}$ and Cardinali F: Dermal, oral, and inhalation pharmacokinetics of methyl tertiary butyl ether (MTBE) in human volunteers. Toxicol Sci 77, 195205 (2004)

20) Fisherova-Bergerova V, Pierce JT and Droz PO: Dermal absorption potential of industrial chemicals: criteria for skin notation. Am J Ind Med 14, 97-107 (1990)

21) Periago JF, Zambudio A and Prado C: Evaluation of environmental levels of aromatic hydrocarbons in gasoline service stations by gas chromatography. J Chromatogr A 778, 263-268 (1997) 